\title{
HUBUNGAN KECERDASAN EMOSIONAL DAN UMUR MAHASISWI SEMESTER I DIV KEBIDANAN TAHUN 2017
}

\author{
Triwik Sri Mulati \\ Kementerian Kesehatan Politeknik Kesehatan Surakarta Jurusan Kebidanan
}

\begin{abstract}
Emotional Intelligence, Age, First Semester Students Of Div Mdwifery Programme. The aim of this research was to know the descriptive of the type and the level of perineum laceration on post partum mother at Klaten. This research was descriptive design. The data were analyzed using descriptive statistics. The respondents were 48 students who are the first semester students of DIV Mdwifery Programme at Poltekkes Kemenkes Surakarta. The results of this study indicate $p=0359$, where $p>$ 0.05 , so it can be concluded that there is no relationship between emotional intelligence and age on the students DIV DIV Mdwifery Programme at Poltekkes Kemenkes Surakarta.
\end{abstract}

Keyword: Emotional Intelligence, Age, First Semester Students Of Div Mdwifery Programme

\begin{abstract}
Abstrak: Kecerdasan Emosional, Umur, Mahasiswi Semester 1 DIV Kebidanan. Penelitian ini bertujuan untuk mengetahui hubungan kecerdasan emosional dan umur mahasiswi semester 1 DIV Kebidanan di Jurusan Kebidanan Poltekkes Kemenkes Surakarta. Jenis penelitian ini adalah penelian analitik korelasi dan menggunakan analisis data Spearman Rank. Sampel dalam penelitian ini yaitu seluruh mahasiswi semester 1 DIV Kebidanan di jurusan Kebidanan Poltekkes Kemenkes Surakarta sejumlah 44 orang. Hasil penelitian ini menunjukkan $p=0.359$, dimana $p>0.05$, sehingga dapat disinpulkan bahwa tidak ada hubungan antara kecerdasan emosional dengan umur pada mahasiswi DIV Kebidanan semester 1 Jurusan kebidanan Poltekkes Kemenkes Surakarta
\end{abstract}

Kata Kunci: Kecerdasan Emosional, Umur, Mahasiswi Semester 1 DIV Kebidanan

\section{PENDAHULUAN}

Berdasarkan teori dari para pakar mengungkapkan bahwa salah satu yang mempengaruhi hasil belajar seseorang adalah kecerdasan emotional orang tersebut. Tidak dipungkiri bahwa ketika seorang tenaga pendidik mendidik anak didiknya, mereka banyak yang kurang memperdulikan bahkan cenderung melupakan tentang kondisi kecerdasan emosional yang dimilki oleh anak didiknya. Padahal jika kecerdasan emosional dikembangkan di institusi pendidikan akan mengoptimalkan hasil belajar anak didik. Berdasarkan penelitian yang telah dilakukan oleh Wahyuningsih (2004) pada 148 siswa kelas II SMU Lab School Jakarta Timur membuktikan bahwa ada hubungan antara kecerdasan emosional dengan prestasi belajar dengan nilai $\mathrm{p}=0,002<0,05$.

Istilah "kecerdasan emosional" pertama kali dikemukakan pada tahun 1990 oleh psikolog Peter Salovey dari 
Harvard University dan John Mayer dari University of New Hampshire untuk menerangkan kualitas-kualitas emosional yang tampaknya penting bagi keberhasilan. Solvey dan Mayer mendefinisikan kecerdasan emosional sebagai Himpunan bagian dari kecerdasan sosial yang melibatkan kemampuan memantau perasaan sosial yang melibatkan kemampuan pada orang lain, memilah-milah semuanya dan menggunakan informasi ini untuk membimbing pikiran dan tindakan (Shapiro, 1998:8). Harmoko (2005), mengatakan yang dimaksud dengan kecerdasan emosional adalah kemampuan untuk mengenali, mengelola, dan mengekspresikan dengan tepat, termasuk untuk memotivasi diri sendiri, mengenali emosi orang lain, serta membina hubungan dengan orang lain. Jelas bila seorang individu mempunyai kecerdasan emosional tinggi, dapat hidup lebih bahagia dan sukses karena percaya diri serta mampu menguasai emosi atau mempunyai kesehatan mental yang baik. Pandangan tersebut didukung pendapat yang dikemukakan Cooper (1995) bahwa kecerdasan emosional memungkinkan individu untuk dapat merasakan dan memahami dengan benar, selanjutnya mampu menggunakan daya dan kepekaan emosinya sebagai energy informasi dan pengaruh yang manusiawi.

Sementara itu Goleman (1997) mengungkapkan lima wilayah kecerdasan emosional yang dapat menjadi pedoman bagi individu untuk mencapai kesuksesan dalam kehidupan sehari-hari yaitu: mengenali emosi diri, mengelola emosi, mengenali emosi orang lain, membina hubungan dengan orang lain dan memotivasi diri.
Penelitian ini bertujuan untuk membuktikan hubungan kecerdasan emosional dan umur mahasiswi semester I DIV Kebidanan Jurusan Kebidanan Poltekkes Kemenkes Surakarta.

Penelitan ini bermanfaat untuk memberikan masukan tentang hubungan kecerdasan emosional dan umur mahasiswi kepada para staf pengajar di DIV Kebidanan Poltekkes Kemenkes Surakarta dan secara umum kepada seluruh staf pengajar di institusi pendidikan.

\section{METODE PENELITIAN}

Jenis penelitian ini adalah analitik, dimana peneliti menguji hubungan dua variabel yaitu variabel dependen dan independen. Sampel dalam penelitian ini adalah mahasiswi DIV Kebidanan semester I sejumlah 44 mahasiswi. Instrument dalam penelitian ini adalah lembar kuesioner untuk mendapatkan data kecerdasan emosional dan umur dari sampel penelitian. Analisis data dilakukan dengan menggunakan uji Spearman Rank.

\section{HASIL PENELITIAN}

Hasil penelitian yang berjudul hubungan kecerdasan emosional dan umur mahasiswi semseter I DIV Kebidanan Jurusan Kebidanan Poltekkes Surakarta dapat dideskripsikan sebagai berikut:

\section{Tabel 1}

Distribusi Frekuensi Umur Responden

\begin{tabular}{ccc}
\hline Umur & $\mathbf{N}$ & $\mathbf{\%}$ \\
\hline 17 & 5 & 11.4 \\
18 & 30 & 68.2 \\
19 & 7 & 15.9 \\
20 & 2 & 4.5 \\
\hline Total & 44 & 100 \\
\hline \multicolumn{4}{c}{ Berdasarkan tabel 1 terlihat } \\
bahwa karakteristik & responden \\
berdasarkan & umum, sebagian besar
\end{tabular}


responden berada pada umur 18 tahun sejumlah 30 mahasiswi (68.2\%).

\section{Tabel 2}

\begin{tabular}{lcc}
\multicolumn{2}{c}{\begin{tabular}{c} 
Distribusi Frekuensi Kecerdasan \\
\multicolumn{3}{c}{ Emosional Responden }
\end{tabular}} \\
\hline $\begin{array}{l}\text { Kecerdasan } \\
\text { Emosional }\end{array}$ & N & $\%$ \\
\hline Kurang & 1 & 2.3 \\
Cukup & 5 & 11.5 \\
Baik & 36 & 81.6 \\
Sangat baik & 2 & 4.6 \\
\hline Total & 84 & 100 \\
\hline
\end{tabular}

Berdasarkan tabel 2 terlihat bahwa

kecerdasan emosional responden sebagian besar pada kategori baik sejumlah 36 mahassiswi (81.6 \%).

Hasil uji analisis data kecerdasan emosional dan data umur responden yang menggunakan uji Spearman Rank menunjukkan hasil $\mathrm{p}=0.359$, dimana $\mathrm{p}>$ 0.05 , sehingga dapat disinpulkan bahwa tidak ada hubungan antara kecerdasan emosional dengan umur pada mahasiswi DIV Kebidanan semester 1 Jurusan kebidanan Poltekkes Kemenkes Surakarta

\section{PEMBAHASAN}

Hasil penelitian menunjukkan sebagian besar responden pada umur 18 . Umur 18 termasuk pada usia dewasa. Secara teori menyatakan bahwa umur dewasa akan menyebabkan seseorang memiliki kemampuan untuk mengenali emosinya dengan lebih baik sehingga kecerdasan emosinya berarti juga baik. Seperti yang diungkapkan oleh Goleman (2002) bahwa orang yang cerdas secara emosi tidak berada di apapun situasi yang menghadang dan tahu cara menenangkan diri bawah kekuasaan emosi. Mereka akan cepat kembali bersemangat. Mengelola suasana hati bukan berarti menekan perasaan. Salah satu ekspresi emosi yang biasa timbul bagi setiap orang adalah marah. Menurut Aristoteles marah itu mudah, tetapi untuk marah kepada yang tepat, tingkat yang tepat, waktu, tujuan, dan cara yang tepat, hanya bias dilakukan oleh orang-orang yang cerdas secara emosi.

Mengenali emosi diri sendiri merupakan suatu kemampuan untuk mengenali perasaan sewaktu perasaan itu terjadi. Kemampuan ini merupakan dasar dari kecerdasan emosional. Para ahli psikologi menyebutkan kesadaran diri sendiri sebagai metamood, yaitu kesadaran seseorang akan emosinya sendiri. Menurut Goleman (2002:64), kesadaran diri adalah waspada terhadap suasana hati maupun pikiran tentang suasana hati, bila kurang waspada maka individu menjadi mudah larut dalam aliran emosi dan dikuasai oleh emosi. Kesadaran diri memang belum menjamin penguasaan emosi, namun merupakan salah satu prasyarat penting untuk mengendalikan emosi sehingga individu mudah menguasai emosi.

Selain itu cerdas secara emosi berarti mahasiswa juga akan memiliki kemampuan untuk mengelola emosi. Mengelola emosi merupakan kemapuan individu dalam menangani perasaan agar dapat terungkap dengan tepat atau selaras, sehingga tercapai keseimbangan dalamdiri. Menjaga emosi tetap terkendali merupakan kunci menuju kesejahteraan emosi. Kemampuan untuk menghibur diri sendiri, melepaskan kecemasan, kemurungan dan ketersinggungan dan akibat yang ditimbulkan serta kemampuan untuk bangkit dari perasaan tertekan merupakan kemampuan mengelola emosi diri (Goleman, 2002).

Cerdas secara emosi berarti mahasiswa juga punya ketrampilan dalam memotivasi diri. Orang yang memilki 
ketrampilan dalam memotivasi diri ini cenderung sangat produktif dan efektif dalam segala hal yang mereka hadapi. Banyak cara untuk memotivasi diri antara lain banyak membaca buku, tetap focus pada impian-impian, evaluasi diri dan sebagainya. Individu dengan motivasi dalam dirinya berarti memiliki ketekunan untuk menahan diri terhadap kepuasan dan mengendalikan dorongan hati, serta mempunyai perasaan yang positif, yaitu antusiasme, gairah, optimis, dan keyakinan diri (goleman, 2002).

Kecerdasan emosi berarti mahasiswa juga memilki kemampuan untuk mengenali emosi orang lain. Menyadari dan menghargai perasaan orang lain adalah hal terpenting dalam kecerdasan emosi. Kemampuan untuk mengenali emosi orang lain ini biasa disebut dengan empati. Menurut Goleman (2002:57) kemampuan seseorang untuk mengenali orang lain atau peduli, menunjukkan kemampuan empati seseorang. Individu yang memiliki kemampuan empati lebih mampu menangkap sinyal-sinyal social yang tersembunyi yang mengisaratkan apa yang dibutuhkan orang lain sehingga ia lebih mampu menerima sudut pandang orang lain, peka terhadap perasaan. Memahami orang lain tidak harus mendikte tindakan kita. Menjadi pendengar yang baik tidak harus setuju dengan apapun yang kita dengar orang lain dan lebih mampu untuk mendengarkan orang lain.

Kecerdasan emosinal berarti mahasiswa memilki kemampuan untuk membina hubungan dengan orang Lain. Kemampuan dalam membina hubungan merupakan suatu keterampilan yang menunjang popularitas, kepemimpinan, dan keberhasilan antar pribadi (Goleman,2002:59). Keterampilan dalam berkomunikasi merupakan kemampuan dasar dalam keberhasilan membina hubungan. Individu yang cerdas secara emosi mampu menjalin hubungan dengan siapa saja, orang lain merasa tenteram dan nyaman didekatnya.

Hasil kecerdasan emosional mahasiswi smt I prodi DIV Kebidanan mayoritas dalam kategori baik. Tetapi ternyata uji analisis data Spearman Rank menunjukkan hasil $\mathrm{p}=0.359>0.05$ sehingga tidak ada hubungan antara kecerdasan emosional dengan umur mahasiswi smt I prodi DIV Kebidanan. Hal tersebut dikarenakan umur responden kurang bervariasi karena hanya pada rentang umur di usia 17 sampai 20 tahun.

\section{KESIMPULAN DAN SARAN}

Berdasar hasil analisis data dan pembahasan dapat disimpulkan sebagai berikut: (1) Umur responden mayoritas umur 18 tahun, (2) Kecerdasan emosional responden mayoritas dalam kategori baik, (3) Tidak ada hubungan antara kecerdasan emosional dengan umur mahasiswi semester I DIV Kebidanan Jurusan Kebidanan Poltekkes Surakarta.

Saran yang diajukan yaitu supaya para tenaga pengajar memberikan perhatian kepada kecerdasan emosinal mahasiswa sehingga akan memperlancar proses pembelajaran mahasiswa di institusi pendidikan.

\section{DAFTAR RUJUKAN}

Arikunto,S.(2002), Prosedur Penelitian Suatu Pendekatan Praktek, Jakarta : Rineka Cipta

Departemen Kesehatan, (2002) Kurikulum Pendidkan Diploma III Kebidanan, Jakarta 
Goleman, D. (2002). Emitional Intelligence (terjemahan). Jakata : PT Gramedia Pustaka Utama.

Goleman, D. (2000). Working With Emotional Intelligence (terjemahan). Jakarta : PT. Gramedia Pustaka Utama.

Hakim,T.(2001), Belajar Secara Efektif, Jakarta : Puspa Swara.

Irawan,P.(1996), Teori Belajar, Motivasi, dan Ketrampilan Mengajar.Jakarta PAU-PPAI Universitas Terbuka.

Irwanto. (1997). Psikologi Umum. Jakarta : PT. Gramedia Pustaka Utama.

Sadirman,AM.(1996). Interaksi dan Motivasi Belajar Mengajar, Jakarta : PT Raja Grafindo Persada

Saphiro, L.E. (1998). Mengajarkan Emotional Intelligence Pada Anak. Jakarta : Gramedia.

Simanjutak,B.(1996) Teori Kepribadian, Bandung : Tarsito.

Supartini (2008) Hubungan Motivasi Belajar dengan Hasil Belajar di SMK Al Hidayah I Jakarta Selatan, Skripsi STKIP Purnama Jakarta.

Suryabrata,S. (1998). Psikologi Pendidikan. Jakarta : PT. Raja Grafindo Persada .

Suryabrata,S. 1998. Metodologi Penelitian. Cetakan sebelas. Jakarta : PT RajaGrafindo Persada. Tjundjing, S. (2001). Hubungan Antara IQ, EQ, dan QA dengan Prestasi Studi Pada Siswa SMU. Jurnal Anima Vol.17 no. 1

Purwanto,N.(2004), Psikologi Pendidikan, Bandung : PT Remaja Rosdakarya Wahyuingsih,AS.(2004) Hubungan Antara Kecerdasan Emosional dengan Prestasi Belajar pada Siswa Kelas II SMU Lab School
Jakarta Timur, Skripsi, Fakultas Psikologi Universitas Persada Indonesia Jakarta

Winkle,WS (1999), Psikologi Pengajaran, Jakarta : PT Grasindo

Winkel, WS (1997). Psikologi Pendidikan dan Evaluasi Belajar. Jakarta : Gramedia

Wirawan,S. (1997). Psikologi Remaja. Jakarta : PT. RajaGrafindo 